\title{
ע Kuluttajadatan mahdollisuudet ja haasteet kansanterveystutkimuksessa; case LoCard
}

Kuluttajadata on tuottanut merkittävää lisäarvoa erityisesti elinkeinoelämälle, mutta yksilön valintoihin liittyvät, kansanterveydelliset ja tutkimukselliset mahdollisuudet alkavat vasta tulla esiin. Suomen keskittynyt päivittäistavaramarkkina mahdollistaa väestön elintapojen tarkastelun jo yhden suuren toimijan datan avulla. Teema-artikkelissa arvioimme kuluttajadatan mahdollisuuksia ja haasteita kansanterveystutkimuksessa suomalaisen LoCard-tutkimuksen aineiston pohjalta. S-ryhmän asiakasomistajille lähetettiiin sähköinen suostumuslomake ja tiedote, jossa heitä pyydettiin luovuttamaan ostotietonsa tutkimustarkoitukseen. Aineisto koostuu 14595 asiakasomistajan ja henkilöstön yli 13 miljoonasta ruoka-, alkoholi- ja tupakkaostotapahtumasta vuoden ajalta. Tutkittavien keski-ikä on 46 (vaihteluväli 16-90) vuotta ja heistä $68,5 \%$ on naisia. Vuosiostojen kokonaissummaa määrittivät sukupuoli ja ikä. Olut ja tupakka olivat ostetuimpien tuoteryhmien joukossa (€/vuosi). Tutkimusnäkökulmasta aineiston vahvuuksia ovat suuri koko, pitkä ajallinen ulottuvuus, objektiivisuus ja ostotapahtumatietojen yksityiskohtaisuus. Haasteita ovat aineiston osittainen valikoituneisuus, tuoteryhmittelyn epätarkoituksenmukaisuus sekä puuttuva tieto ostojen ja yksilötason kulutuksen kohtaavuudesta. Suomalaisille kauppaketjuille kertyvät ostotiedot ovat terveystutkimuksen näkökulmasta lähes ilmainen oheistuote, jotka syntyvät jo olemassa olevissa rakenteissa ja joita on mahdollista hyödyntää riippumattomassa tutkimuskäytössä. Aineiston tiedollinen potentiaali kasvaa muihin väestöaineistoihin yhdistettäessä. Kuluttajadatan avulla on mahdollista tarkastella keskeisten kansansairauksiemme riskitekijöitä, elintapojen kasaantumista ja niiden alueellisia sekä sosioekonomisia eroja aiempaa laajemmin ja yksityiskohtaisemmin. Tutkimuksen löydöksiä voidaan käyttää eriarvoisuuden tunnistamiseen ja siihen puuttumiseen. LoCard-tutkimus tarjoaa myös näyttöä yritysten yhteiskuntavastuullisen toiminnan kehittämiseksi.

ASIASANAT: kuluttaja, tutkimusaineisto, kansanterveys, ostokäyttäytyminen MAIJALIISA ERKKOLA, MIKAEL FOGELHOLM, HANNU SAARIJÄRVI, LIISA UUSITALO, JAAKKO NEVALAINEN

\section{YDINASIAT}

- Kuluttajadatan vahvuuksia ovat suuri koko, ajallinen ulottuvuus, objektiivisuus, tietojen yksityiskohtaisuus, kerääntymisen automaattisuus ja kustannustehokkuus. Toistaiseksi tätä aineistoa on kuitenkin hyödynnetty terveystutkimuksessa vain niukasti.
- Haasteita ovat osittainen valikoituneisuus, tuoteryhmittelyn mahdollinen epätarkoituksenmukaisuus ja puuttuva tieto ostojen ja yksilötason kulutuksen kohtaavuudesta.

- Kuluttaja-aineistoja on mahdollista hyödyntää kansanterveyden ja kestävän kulutuksen seurantaan, edistämiseen sekä eriarvoisuuden kaventamiseen. 


\section{JOHDANTO}

Keskeiset kansanterveyshaasteemme ylipaino, tyypin 2 diabetes, sydän- ja verisuonitaudit, osa syöpätaudeista sekä masennus liitetään haitallisiin elintapoihin; epäterveellinen ruokavalio, tupakointi ja alkoholinkäyttö lisäävät niiden riskiä (1). Mainittujen riskitekijöiden kasaantuminen yksittäisille väestöryhmille synnyttää terveyden eriarvoisuutta (2). Väestön elintapojen kustannustehokas ja ajantasainen arviointi on edellytys riskiryhmien tunnistamiselle sekä terveyttä edistävien toimenpiteiden tulokselliselle kohdentamiselle. Ruoankäyttö on elintavoista kenties haastavin mitattava. Käytössä olevat ruoankäytön tutkimusmenetelmät, kuten frekvenssikysely ja ruokapäiväkirja, sisältävät useita satunnaisia ja systemaattisia virhelähteitä, ja kunkin menetelmän tuottamassa tiedossa on omat puutteensa $(3,4)$. Lisäksi ihmisillä on taipumus raportoida ruoankäyttöään todellisuutta terveellisemmäksi ja sosiaalisesti toivottavaksi, mikä on erityinen haaste $\mathrm{mm}$. alkoholin kulutusta tutkittaessa (5). Suomalaisten innostus osallistua elintapoja kartoittaviin tutkimuksiin on ollut laskusuunnassa (6) ja vaarana on päätyä tutkimaan lähinnä terveystietoisten ja koulutettujen keski-ikäisten naisten väestöryhmiä, joissa keskeisten elintapaindikaattorien lähtötaso on jo valmiiksi suhteellisen hyvä ja hajonta pientä. Tällöin jäävät saavuttamatta terveydenedistämistoimien tärkeimmät kohderyhmät, joille kasaantuvat sekä haitalliset elintavat että sosiaali- ja terveydenhuollon suurimmat menot.

Modernin teknologian myötä suurten datamäärien kerääminen ja tallentaminen ovat helpottuneet huomattavasti. Samaan aikaa tietokoneiden laskentateho on lisääntynyt räjähdysmäisesti, mikä mahdollistaa suurten aineistojen tehokkaan analysoinnin ja niistä oppimisen tilastotieteen, koneoppimisen, tietojenkäsittelytieteiden tai niiden yhdistelmien keinoin. Suurteholaskennan merkitys onkin kasvussa yhä useammilla tieteenaloilla: esimerkiksi digitaalisen epidemiologian nouseva tieteenala pyrkii massadatan (big data) avulla havaitsemaan ja ymmärtämään kansanterveysongelmia aiempaa paremmin (7). Massadata on jo tähän mennessä tuottanut merkittävää lisäarvoa erityisesti elinkeinoelämälle sekä tutkimuksessa esimerkiksi solutason ilmiöiden ymmärtämiseen, mutta kansanterveydelliset ja yksilön valintoihin liittyvät hyödyt alkavat vasta tulla esiin (8).
Oikein segmentoitu, laadukas, analysoitu ja hyvin esitetty data on kiistatta arvokasta, mutta näyttö ei-tieteelliseen tarkoitukseen kerättyjen tietovarantojen luotettavuudesta on vielä osin puutteellista ja datan käyttöön sisältyy mm. eettisiä haasteita (9). Toisena haasteena massadatojen käytössä ovat datan omistajuuskysymykset ja yritysten liiketoimintatavoitteet, jotka rajoittavat datojen vapaata käyttöä tieteellisessä tutkimuksessa. Suomessa on julkaistu massadataan liittyviä strategioita (10) ja käynnistetty avoimen tieteen ja tutkimuksen hanke (www.avointiede.fi). Strategia kohdistaa huomion tiedon keräämisestä tiedon hyödyntämiseen yksilön omassa elämässä ja tutkimuksessa sekä korostaa tiedon uusiokäyttöä. Massadata on muuttamassa tutkimuksen toimintakulttuuria ja se lisää avoimuuden ja yhteistyön tarvetta.

Kuluttaja-aineistot ovat massadatojen laajassa kirjossa huomattavan houkuttelevia, sillä ne heijastelevat yksittäisten ihmisten tai kotitalouksien elintapoja ja pitkittäisyytensä ansiosta mahdollistavat elintapojen muutosten arvioinnin. Kuluttajien ostotietoja on kansanterveystutkimuksessa hyödynnetty useisiin tarkoituksiin: terveyden edistämiseen tähtäävien interventioiden ja ohjauskeinojen vaikuttavuuden arvioimiseen (11-13), ruoka- ja alkoholiostoja määrittävien tekijöiden kartoittamiseen $(14,15)$, ruoankäytön alueellisten erojen selvittämiseen $(15,16)$ sekä ostosten ravitsemuslaadun arvioimiseen (17-22). Kotitaloustason ostotiedot ovat pohjanneet joko ostokuitteihin, ostokirjanpitoon, skannattuihin viivakoodeihin tai kotiinkuljetusten ostotietoihin (21). Pääosin kuluttajien itsensä keräämä aineisto on altistunut perinteisille ruoankäytön tutkimisen virhelähteille; otoksen valikoitumiselle sekä virheraportoinnille. Yksittäisten myymälöiden tai myymäläketjujen myyntitietoja voidaan hyödyntää ekologisissa analyyseissä mm. väestöryhmien ostosten ravitsemuslaadun tai terveyskäyttäytymisen kuvaajana $(11,16)$. Sekä kotitaloustason että myymälätason ostodatan hyödyntämistä heikentää puutteellinen tieto kuluttajadatan luotettavuudesta yksilön ruoankäytön kuvaajana. Kattavasti koostettu kotitaloustason ostodata on validointitutkimusten perusteella suhteellisen luotettava yksilöiden ruokavalion laadun mutta heikommin ravintoaineiden saannin kuvaaja (19-24). 
Päivittäistavarakaupat keräävät tietoa asiakkaidensa käyttäytymisestä erityisesti kanta-asiakasjärjestelmien avulla. Kuluttajan käyttäessä kanta-asiakaskorttia ostosten yhteydessä ostotiedot kumuloituvat asiakaskohtaisesti. Päivittäistavarakaupat voivat kerätä tietoa ostoksista eri tarkkuustasoilla (esim. ostoksen loppusumma-, tuoteryhmä-, tuoterivitasoinen tieto) ja viime vuosina kaupan alan yritykset ovat siirtyneet tarkempaan ostotiedon keräämiseen (25). Kantaasiakasjärjestelmien avulla kerättyä tietoa voidaan hyödyntää esimerkiksi päivittäistavarakauppojen valikoimien kehittämiseen, uusien ruokatrendien tunnistamiseen ja ymmärtämiseen, markkinointiviestinnän kohdentamiseen ja kuluttajasegmentointiin (26). Tieto voi siis sekä lisätä yrityksen ymmärrystä asiakkaidensa tarpeista että ohjata yrityksen prosesseja (27). Tiedon hyödyntäminen on kuitenkin ollut pääosin yksisuuntaista: kanta-asiakastietojen hyödyntäminen on fokusoitunut lähinnä yritysten tarpeisiin (28). Ranskalaisen kauppaketjun kanta-asiakastietoja on hyödynnetty onnistuneesti myös kansanterveystutkimuksessa (29).

Teema-artikkelissamme esittelemme laajan suomalaisen ruoka-, alkoholi- ja tupakkaostotietoja sisältävän LoCard-asiakasomistaja-aineiston (https://locard.fi), joka on useimmista kotitalouden ostoja mitanneista aiemmista tutkimuksista poiketen kertynyt ostotapahtumien yhteydessä ilman tutkittavien aktiivista panosta. Arvioimme aineiston sisäistä ja ulkoista luotettavuutta tutkimuskäytössä sekä pohdimme tulostemme ja aiemman kirjallisuuden valossa kuluttajadatan mahdollisuuksia ja haasteita kansanterveystutkimuksessa.

\section{AINEISTO JA MENETELMÄT}

Helsingin ja Tampereen yliopistot ovat käynnistäneet yhteistyön osuustoiminnallisen S-ryhmän kanssa osana S-ryhmän uutta yhteiskuntavastuullista toimintaa. S-ryhmällä on käytössä S-etukorttien käyttöön pohjautuva kanta-asiakasjärjestelmä, joka mahdollistaa ostotietojen keräämisen yrityksen asiakasomistajilta. Osana yhteistyötä S-ryhmä pyysi huhti-toukokuussa 2017 HOKElanto-alueen asiakasomistajilta ja henkilöstöltä sähköpostitiedotteella suostumusta S-Etukorttien avulla kerätyn ostotiedon luovuttamiseen tutkimuskäyttöön. Tiedote ja siihen linkitetty sähköinen suostumuslomake lähetettiin yhteensä
245877 (27\% kaikista) Helsingin Osuuskauppa Elannon asiakasomistajalle ja 13763 (56 \% kaikista) S-ryhmän henkilöstöön kuuluvalle, joiden sähköpostiosoite oli S-ryhmän tiedossa. S-ryhmä luovutti tutkimukseen suostuneiden asiakasomistajien S-Etukorttien ostotiedot tutkimusryhmän käyttöön ilman henkilökohtaisia tunnistetietoja. Tiedot luovutettiin vain tutkimukseen suostuneen (ei muiden perheenjäsenten) henkilön ostojen osalta ostotapahtumista, jotka oli tehty ajalla 1.1.-31.12.2016 Prismoissa, S-marketeissa, ABC-marketeissa sekä Alepa ja Sale-myymälöissä. Helsingin yliopiston ihmistieteiden eettisen ennakkoarvioinnin toimikunta myönsi tutkimukselle puoltavan lausunnon.

Edellä kuvatun pilottivaiheen aineiston lisäksi tutkimusryhmä kerää samalla menetelmällä laajemman koko maan kattavan, yli kahden vuoden ostotiedot sisältävän aineiston. Ostotietojen lisäksi suostumuslomakkeen oheen linkitetyllä vapaaehtoisella kyselylomakkeella kerättiin monipuolisesti tietoa mm. tutkittavien sosiodemografisista taustatekijöistä sekä elintavoista. Tämä teemakäsikirjoitus käsittelee pilottivaiheen aineistoa.

\section{TULOKSET}

LoCard-tutkimuksen pilotti-aineiston muodostavat yhteensä 14595 Helsingin Osuuskauppa Elannon asiakasomistajaa ja S-ryhmän henkilöstön jäsentä (5,6 \% kutsutuista) sekä heidän vuoden 2016 päivittäistavaroiden ostotapahtumansa (> 13 miljoonaa tapahtumaa). Taustatiedot: postinumero, syntymävuosi ja sukupuoli saatiin yhteensä 14522 tutkittavalle: 13274 asiakasomistajalle $(5,4 \%)$ ja 1248 henkilöstön jäsenelle $(9,1 \%)$. Pääosa asiakasomistajista on Etelä-Suomen alueelta, mutta henkilöstö edustaa koko Suomea. Asiakasomistajista 67 \% (8937) ja henkilöstöstä $80 \%$ (1004) on naisia. Henkilöstön otoksen keski-ikä $(40,1$, keskihajonta 11,6$)$ on 6 vuotta alhaisempi kuin asiakasomistajien otoksessa $(46,2$, keskihajonta 14,7).

Aineisto on luonteeltaan hienojakoinen pitkittäisaineisto, johon liittyy paikkatieto (asuinpaikan postinumero). Ostokset on luokiteltu 184 tuoteryhmätasolle (esim. oluet, savukkeet, kestomakkarat) ja datasta selviää myös ostojen päivämäärä ja kellonaika. Kuviossa 1 on havainnollistettu päivittäistavarakaupassa saatavilla olevien oluiden, siiderien savukkeiden, vihannesten ja 


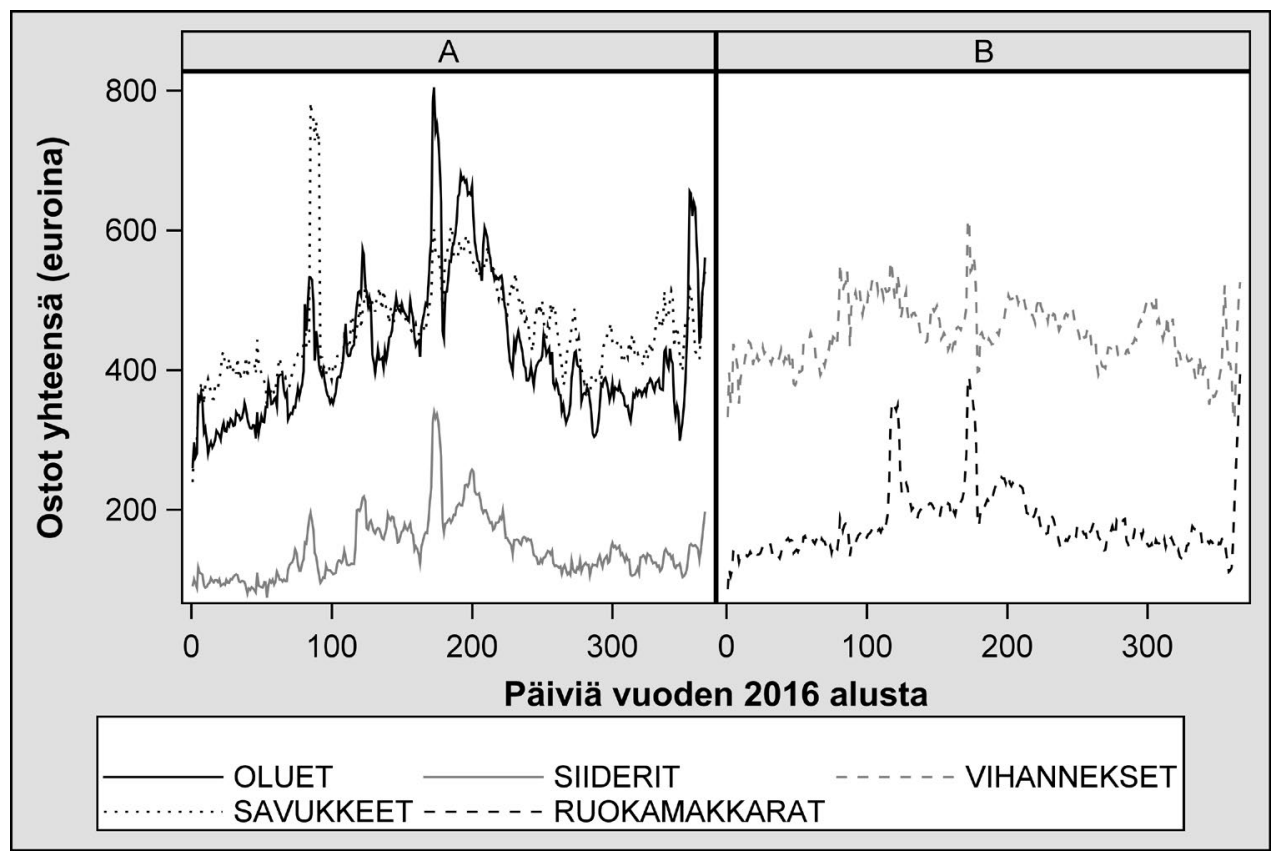

Kuvio 1. Valittujen tuoteryhmien päivittäiset kokonaisostot (seitsemän päivän liukuva keskiarvo)

ruokamakkaroiden ostoja (Kuvio 1). Keskimääräiset vuosiostot olivat asiakasomistajilla $2443 €$ ja henkilöstöllä $4419 €$. Iän, sukupuolen ja kunnan mukaan painotettu ostojen keskiarvo oli $2322 €$. Vuosiostojen kokonaissummaa määrittävät asiakasomistajilla sukupuoli ja ikä; summa on korkein miehillä ja keski-ikäisillä. Perjantai ja lauantai olivat vilkkaimpia ostopäiviä ja sunnuntai ja tiistai vähiten vilkkaita.

Olut ja savukkeet olivat ostetuimpien tuoteryhmien joukossa (Taulukko 1). Henkilöstöllä tupakkaostot olivat kaksinkertaisia asiakasomistajiin verrattuna.

\section{KULUTTAJA-AINEISTON ULKOINEN VALLDITEETTI}

\section{AINEISTON EDUSTAVUUS}

Viimeisten vuosikymmenten aikana suomalaisten väestötutkimusten osallistumisaktiivisuus on laskenut (30), ja myös tässä tutkittavan suostumukseen perustuvassa ostodatatutkimuksessa osallistumisprosentti jäi alhaiseksi jopa kyselytutkimuksiin verrattuna. Aineiston epäkonventionaalinen syntytapa (on asiakasomistaja tai henkilöstön jäsen, on antanut sähköpostiosoitteensa ja on antanut suostumuksensa) johti siihen, että tutkimukseen päätyneiden kortinomistajien otos on valikoitunut. Nuoret ja hyvin iäkkäät asiakasomistajat ovat LoCard-tutkimuksen otoksessa aliedustettuja, Helsingin kaupungissa asuvat asiakasomistajat puolestaan yliedustettuja. Yleisesti tutkimuksiin jättävät osallistumatta nuoret, miehet, naimattomat, vähiten koulutetut, alhaisimpaan tuloluokkaan kuuluvat sekä ulkomaalaistaustaiset $(6,31,32)$. Mainituista tekijöistä $\mathrm{mm}$. vähäinen koulutus ja alhaiset tulot, nuori ikä, miessukupuoli ja naimattomuus lisäävät epäterveellisten elintapojen todennäköisyyttä (33) ja vinoutuneet otokset antavat siten todellista paremman kuvan väestön elintavoista. Vuosina 1997-2012 FINRISK-tutkimuksissa kaupunkilaisnaisten osallistumisaktiivisuus oli pienempi kuin maaseudulla asuvien naisten (30), mikä on osin vastakkaista LoCard-tutkimuksen otoksen kanssa.

LoCard-tutkimukseen pilottivaiheeseen osallistuneiden sosioekonomisesta taustasta ei ole saatavilla kattavaa tietoa. Henkilöstöotoksen voi kuitenkin olettaa olevan matalammin koulutettua kuin suomalaistyöntekijät keskimäärin. Vähittäiskaupan alan työntekijöistä $13 \%$ :lla on perusasteen koulutus (vähemmän kuin lukio), $62 \%:$ :lla keskiasteen koulutus (lukio, ammatillinen koulutus) ja $25 \%$ :lla korkea-asteen koulutus (ammattikorkeakoulu tai enemmän), (34). 
Taulukko 1. Kymmenen ostetuimman (€/vuosi) tuoteryhmän vuosittaisten ostosummien ja ostokertojen jakaumat asiakasomistajilla ja henkilöstöllä

\begin{tabular}{|c|c|c|c|c|c|c|c|c|c|c|}
\hline \multirow[t]{2}{*}{ Tuoteryhmä } & \multirow{2}{*}{$\begin{array}{c}\text { Alaotos } \\
\text { A=asiakas- } \\
\text { omistajat } \\
\text { H=henkilöstö }\end{array}$} & \multirow{2}{*}{$\begin{array}{c}\text { Ostajien } \\
\text { osuus } \\
(\%)\end{array}$} & \multicolumn{4}{|c|}{ Ostojen kokonaissumma $€ /$ vuosi } & \multicolumn{4}{|c|}{ Ostokerrat / vuosi } \\
\hline & & & $\begin{array}{c}\text { Ala- } \\
\text { kvartiili }\end{array}$ & Mediaani & $\begin{array}{c}\text { Ylä- } \\
\text { kvartiili }\end{array}$ & Maksimi & $\begin{array}{c}\text { Ala- } \\
\text { kvartiili }\end{array}$ & Mediaani & $\begin{array}{c}\text { Ylä- } \\
\text { kvartiili }\end{array}$ & Maksimi \\
\hline \multirow{2}{*}{$\begin{array}{l}\text { Eines- } \\
\text { valmisteet }\end{array}$} & $\mathrm{A}$ & 93 & 12 & 40 & 97 & 2555 & 4 & 12 & 27 & 350 \\
\hline & $\mathrm{H}$ & 99 & 46 & 111 & 221 & 1534 & 15 & 34 & 65 & 251 \\
\hline \multirow{2}{*}{ Juusto } & A & 98 & 46 & 106 & 198 & 3120 & 12 & 26 & 45 & 252 \\
\hline & $\mathrm{H}$ & 100 & 121 & 202 & 307 & 1145 & 31 & 48 & 68 & 236 \\
\hline \multirow{2}{*}{ Maito ja kerma } & A & 98 & 27 & 67 & 37 & 1579 & 16 & 35 & 63 & 314 \\
\hline & $\mathrm{H}$ & 100 & 70 & 136 & 258 & 1467 & 39 & 64 & 94 & 361 \\
\hline \multirow{2}{*}{ Naudanliha } & A & 80 & 4 & 23 & 69 & 1022 & 1 & 5 & 13 & 176 \\
\hline & $\mathrm{H}$ & 94 & 20 & 67 & 143 & 1016 & 4 & 13 & 27 & 107 \\
\hline Oluet & A & 72 & 0 & 17 & 79 & 6938 & 0 & 3 & 11 & 685 \\
\hline$<4.7 \%$ & $\mathrm{H}$ & 82 & 6 & 40 & 121 & 5301 & 1 & 5 & 15 & 554 \\
\hline \multirow{2}{*}{ Savukkeet } & $\mathrm{A}$ & 29 & 0 & 0 & 11 & 8063 & 0 & 0 & 1 & 387 \\
\hline & $\mathrm{H}$ & 43 & 0 & 0 & 103 & 8222 & 0 & 0 & 13 & 430 \\
\hline \multirow{2}{*}{ Siipikarjan liha } & A & 86 & 9 & 35 & 88 & 1703 & 2 & 7 & 17 & 249 \\
\hline & $\mathrm{H}$ & 97 & 45 & 93 & 168 & 1091 & 10 & 19 & 31 & 171 \\
\hline \multirow{2}{*}{$\begin{array}{l}\text { Tuore } \\
\text { ruokaleipä }\end{array}$} & A & 98 & 23 & 55 & 109 & 1026 & 12 & 27 & 48 & 333 \\
\hline & $\mathrm{H}$ & 100 & 58 & 111 & 191 & 789 & 29 & 51 & 79 & 269 \\
\hline \multirow{2}{*}{ Vihannekset } & A & 98 & 26 & 66 & 128 & 1286 & 13 & 29 & 51 & 296 \\
\hline & $\mathrm{H}$ & 100 & 61 & 112 & 181 & 1030 & 30 & 47 & 68 & 244 \\
\hline \multirow{2}{*}{$\begin{array}{l}\text { Virvoitus- } \\
\text { juomat, vedet }\end{array}$} & A & 93 & 7 & 25 & 65 & 1692 & 4 & 12 & 30 & 410 \\
\hline & $\mathrm{H}$ & 99 & 31 & 69 & 155 & 1465 & 16 & 32 & 66 & 664 \\
\hline
\end{tabular}

Suomalaistyöntekijöillä vastaavat osuudet ovat $10 \%, 45 \%$ ja $45 \%$. Tätä voi osaltaan selittää se, että kaupan ala on perinteisesti suurin nuorten työllistäjä ja se työllistää paljon opiskelun ohessa työtä tekeviä (35). Osa-aineistona henkilöstö on monella tapaa kiinnostava. Yhteiskunnassamme on meneillään useita nopeutuvia muutoksia: digitalisaatio, sosiaaliturvan rakenteiden muutos, erilaisten elämäntilanteiden lisääntyminen elämänkaaren aikana sekä asumisen muodon muuttuminen laadullisesti ja alueellisesti (36). Nämä muutokset osuvat erityisen voimakkaasti palvelualoilla suorittavissa tehtävissä oleviin henkilöihin kuten myyjiin. Aineistomme kattaa tämän ryhmän poikkeuksellisen hyvin, koska henkilöstön osallistumisaktiivisuus oli asiakasomistajia korkeampi.

Tutkimuksemme osoittaa, että kuluttajadatan käyttö tarjoaa mahdollisuuden kerätä laaja ja mahdollisesti myös vähemmän valikoitunut tutkimusaineisto väestötutkimuksia huomattavasti pienemmillä resursseilla. Aineisto ei kuitenkaan kata kaikkia alaryhmiä, jotka tyypillisimmin jättävät vastaamatta tutkimuksiin. Lisäksi sähköi- nen lähestymistapa luultavasti karsii iäkkäimpiä tutkittavia, joiden osuus väestöstä tulee jatkossa kasvamaan. Tosin väestön ikääntyessä myös digitaalisten valmiuksien voidaan olettaa suhteellisesti kehittyvän myönteisempään suuntaan. Kuluttaja-aineiston havaintoja voikin olla tarkoituksenmukaista korjata painokerrointen avulla, mikäli otoksen edustavuutta tutkiva katoanalyysi osoittaa aineistossa systemaattisia vinoutumia. Tämä edellyttää tietoa osallistumattomuuteen liittyvistä tekijöistä, jotka eivät välttämättä ole samoja kuin perinteisissä väestötutkimuksissa. Katoanalyysien menetelmällistä kehittämistä tulisikin tehdä enenevästi myös toissijaiseen käyttöön hyödynnettävän massadatan näkökulmasta.

Yhä heterogeenisempi väestö yhdessä laskevan osallistumisaktiivisuuden kanssa tekee laajat elintapatutkimukset jatkossa yhä vaikeammiksi toteuttaa. Edustavan väestöotoksen rekrytoiminen käy yhä haastavammaksi. Nopeasti muuttuva elintarvikevalikoima edellyttää ajantasaista elintarvikkeiden koostumustietokantaa sekä yksilöiden välisiä eroja luotettavasti mittaavaa ruoankäytön tutkimusmenetelmää. Samanaikaisesti 
digitaalinen kehitys mahdollistaa helpon pääsyn pitkän aikavälin ruokaostotietoihin, jotka mahdollistavat väestöryhmien välisten hienosyistenkin erojen havainnoimisen ajassa. Ostotietojen rinnalle tarvitaan kuitenkin laajempaa tietoa kuluttajien sosiodemografisista tekijöistä. Luottamuksellisia ja tunnistamisen mahdollistavia tietoja kaupalliset toimijat eivät halua tai voi luovuttaa. Kanta-asiakaskortin taustatiedot voivat myös olla puutteellisia tai vanhentuneita esimerkiksi perhekoon tai asuinpaikkakunnan osalta. Lisäksi yrityksillä itsellään on harvoin edellytyksiä ja perusteita kerätä tietoa esimerkiksi asiakkaidensa tulotasosta. Siksi ostotietoja tulee yhdistää puuttuvia tietoja täydentäviin muihin tutkimusaineistoihin tai taustatietoja on kysyttävä ostotiedoista erillisellä kyselylomakkeella.

\section{KULUTTAJA-AINEISTON SISÄINEN VALIDITEETTI: RUOKA-, ALKOHOLI- JA TUPAKKAOSTOT}

Kymmenen ostetuinta tuoteryhmää olivat samat sekä asiakasomistajilla että suuremman osan ostoistaan S-ryhmään keskittävällä henkilöstöllä. Tämä viittaa siihen, että keskittämisasteesta huolimatta yksittäisen suuren kauppaketjun ostotiedot antavat suhteellisen luotettavan kuvan asiakasomistajan kokonaisostojen profiilista. Henkilöstön suuremmat tupakkaostot voivat olla yhteydessä sosioekonomiseen asemaan samoin kuin ostetuimpien tuoteryhmien postinumeroalueittaiset eroavaisuudet. Päivittäistavaramarkkinat ovat pohjoismaissa hyvin keskittyneitä: kolme suurinta kauppaketjua kattavat noin 80 $95 \%$ markkinoista (37). Vuonna 2017 S-ryhmän markkinaosuus oli 47,2 \%, minkä lisäksi suomalaiskuluttajat ovat asiakaskorttien omistajina Euroopan kärkeä (38). Korkea keskittämisaste sekä asiakasuskollisuus mahdollistavat väestötason seurannan jo yksittäisen suuren kauppaketjun ostotietojen pohjalta. Yhteensä 22 ostodatatutkimusta sisältäneen katsauksen (21) mukaan objektiivinen, muistivirheistä vapaa ja monipuolisen vaihtelutiedon sisältävä ostodata tarjoaa perinteisillä ruoankäytön tutkimusmenetelmillä tuotettuihin aineistoihin verrattuna monipuolisemman mahdollisuuden ruoankäytön väestöryhmittäisten, alueellisten ja ajallisten erojen tarkasteluun. Yksittäisten aineistojen luotettavuuteen vaikuttavat mm. kotitalouden ostotietojen kattavuus sekä se raportoiko kuluttaja itse ostoksensa vai saadaanko tiedot automaattisesti kauppojen järjestelmästä.

\section{KULUTTAJA-AINEISTON KÄYTTÖ KANSANTERVEYS- TUTKIMUKSESSA}

\section{HAASTEET}

Kuluttajadatan suurimpana haasteena on se, että tiedot kerätään osittain kotitalouden ja osittain yksilön tasolla. Ostotietojen tarkka tallentuminen ei suoraan kerro, kuka ostettua ruokaa, alkoholia ja savukkeita on kuluttanut. Ruokaa, alkoholia ja tupakkaa ostetaan myös asiakasomistajasuhteen ulkopuolisista paikoista: kioskeista, toreilta ja muista myymälöistä. Tämän lisäksi syödään ulkona ja työpaikalla sekä tarjotaan oman ostoskassin tuotteita vieraille ja lemmikkieläimille. Ostotiedot kuvaavatkin yksilötason ruoankäyttöä vain osittain. Aiemmat tutkimukset ovat kuitenkin osoittaneet, että kattavilla kotitaloustason ostotiedoilla voidaan suhteellisen luotettavasti mallintaa yksilötason ruokavaliotyylejä (20-24).

Asiakasomistaja-aineiston arvo on suorassa suhteessa ostotietojen tarkkuustasoon. Asiakasomistajien ostoista voidaan kerätä tietoa ostosten arvon tasolla (esim. ostokset 45,34 €), tuoteryhmätasolla (esim. vihanneksia 24,20 €), tai tuotetasolla (esim. porkkanoita 4,20 €). Tuoteryhmiä ei ole välttämättä ryhmitelty selkeisiin kategorioihin, jotka olisivat suoraan käyttökelpoisia esim. ostojen terveysvaikutusten tutkimiseen, vaan niiden jakoperuste on voinut perustua esimerkiksi liiketaloudellisiin, logistisiin tai tietojärjestelmällisiin syihin. Ravitsemustieteessä käytetyt ryhmittelyt pohjaavat pääosin aiempaan tietoon ravintotekijöiden ja terveyden välisistä yhteyksistä. Tutkimusnäkökulmasta tarkasteltuna epäjohdonmukaisesti ryhmitelty data, esim. kasviproteiinituotteiden ryhmittely samaan kategoriaan kokolihatuotteiden kanssa, heikentää suurenkin tietomäärän käytettävyyttä.

Massadatan, josta ostodata on yksi esimerkki, yhtenä ongelmana voidaankin nähdä se, että tiedon keräämisen helppouden ja suuren aineiston hintana on usein edustavuuden ja mittaamisen instrumenttien hämärtyminen. Kaupalliseen ja kansanterveystutkimukseen kerättyjen aineistojen lähtökohtien erilaisuus on tärkeä ymmärtää; kaikki kuluttaja-aineistot eivät sovi kansanterveystutkimuksen pohjaksi. Aineiston suuri koko 
voi johtaa harhaiseen käsitykseen tulosten luotettavuudesta. Perinteisten tilastollisten menetelmien rinnalle onkin kehitettävä uusia menetelmiä ja tulosten merkitystä on arvioitava muutenkin kuin niiden tilastollisen merkitsevyyden suhteen. Tarvitaan menetelmiä arvioida epävarmuutta paitsi rajallisen otoksen myös tietolähteeseen liittyvän erityisen kertymistavan suhteen. Tieteellisen tiedon itsekorjautuvuuden toteutuminen voi myös osoittautua haasteelliseksi massadatoihin pohjautuvissa tutkimuksissa. Menetelmien läpinäkyvyys mahdollistaa menetelmien kriittisen tarkastelun, mikä on lähtökohta niiden kehittymiselle.

Ostodatan kriittinen tarkastelu validiteetin näkökulmasta sekä menetelmien kehittäminen mahdollisten vääristymien korjaamiseen ovat edellytyksiä tiedon hyödyntämiselle sekä tulosten relevantille tulkinnalle. Ostodatan tiedollinen potentiaali kasvaa, kun siihen yhdistetään eritasoisia tietolähteitä, esim. väestön ruoankäyttötietoa ja sosiodemografisia taustatietoja sekä elintarvikkeiden koostumustietoja. Yksittäisen aineiston ruokaostotietoja on esim. Tanskassa onnistuneesti yhdistetty rekisteritietoihin ja elintarvikkeiden ravintosisältötietoihin (39) sekä yksilötason ruoankäytön frekvenssitietoihin (24).

Massadatan käyttöön sisältyviä eettisiä näkökulmia tulee oppia tunnistamaan ja ratkaisuja tulee etsiä tiedeyhteisön ja sidosryhmien yhteisen dialogin kautta $(9,40)$. Kuluttajista automaattisesti kertyneen aineiston jatkokäytön oikeutus yhteiskuntavastuulliseen tarkoitukseen sekä yksilön oikeudet hallinnoida itsestä kerättyä tietoa voivat johtaa rajanvedon epäselvyyksiin näiden kahden välillä. Kuluttajista kerätyn tiedon yksityisyys onkin viime aikoina noussut esille tietovuotojen ja tiedon väärinkäytön seurauksena (esim. 41). Kuluttajat ovat enenevissä määrin huolissaan siitä, millaisia tietoja heistä kerätään verkkopalvelujen ja sosiaalisen median käytön yhteydessä (37). Julkiset kohut voivat ainakin lyhytaikaisesti vaikuttaa sekä kuluttajien että yritysten halukkuuteen luovuttaa tietojaan tutkimuskäyttöön. Tutkimuseettisen toimikunnan hyväksymä tutkimussuunnitelma lisää tutkimukseen kutsuttavien luottamusta tietojen oikeaan ja luottamukselliseen käyttöön sekä toiminnan läpinäkyvyyteen (9). Kuluttajille on tärkeä viestiä myös mahdollisuudesta peruuttaa annettu suostumus ostotietojen tutkimuskäyttöön. Eetti- nen ennakkoarviointi ohjaa sekä tutkijat että yrityksen myös arvioimaan toimintaansa eettisistä näkökulmista. Tutkimuseettisistä näkökulmista huolehtiminen on tutkijan vastuulla. Yrityksissä ei välttämättä ole tällaista osaamista, jolloin tutkijan on huolehdittava siitä, että tutkimuksen eettiset näkökulmat nostetaan esiin keskusteluissa. Lisäksi tutkijan on hyvä varautua siihen, että näissä keskusteluissa voi olla välttämätöntä avata sitä ajattelua ja niitä periaatteita, joihin päätökset tutkimuksen eettisestä toteutuksesta perustuvat. Helsingin yliopiston ihmistieteiden eettisen ennakkoarvioinnin toimikunta on luonut tutkimuseettisten näkökulmien tarkistuslistan yritysyhteistyönä tehtävään ihmistieteelliseen tutkimukseen (42). EU:n yleinen tietosuojaasetus (GDPR) on luomassa ohjeistusta EU:n alueen yrityksille asiakasdatan hallinnoimiseksi ja riskien torjumiseksi (43). Uudella sääntelyllä halutaan ohjata yhteisöt ja yritykset ottamaan tietosuoja-asiat kokonaisvaltaisesti huomioon jo toimintansa suunnittelussa.

\section{MAHDOLLISUUDET}

Suomalaisille kauppaketjuille kertyvät ostotiedot ovat terveystutkimuksen näkökulmasta lähes ilmainen oheistuote, jotka syntyvät jo olemassa olevissa rakenteissa ja joita on mahdollista hyödyntää riippumattomassa tutkimuskäytössä. Suomen keskittynyt päivittäistavaramarkkina mahdollistaa isojen väestöryhmien ruoankäytön tarkastelun jo yhden toimijan datan avulla. Tämä luo potentiaalia väestön ruokatottumusten seurannalle, arvioinnille sekä kansanterveydelliselle kehittämiselle. Yhden toimijan valikoima- tai toimintatapamuutoksilla on merkittävä vaikutus keskittyneessä markkinassa. Muutokset kotitalouksien ostoskoreissa edustavatkin yhtä keskeistä ulottuvuutta niiden tarkastelussa. Kyselytutkimukset tuottavat muutoksista vain rajallisesti tietoa, kun ostodata puolestaan tarjoaa huomattavan hienojakoisen mahdollisuuden analysoida elintapoja pitkällä aikavälillä. Aiemmin on osoitettu, että esim. painonnousu liittyy epäterveellisten tuotteiden ostoihin tiettyinä aikoina (44). Lisäksi tiettyyn vuorokauden aikaan ajoittuvat alkoholijuomien ostot saattavat viitata alkoholin riskikäyttöön tai riippuvuuteen.

Suomessa on pitkään pyritty ohjaamaan lainsäädännöllä ja valistuksella ostokäyttäytymistä terveellisemmäksi arvioituun suuntaan. Keinoja 
rajoittaa terveydelle haitallisia elintapoja ovat esimerkiksi verotus, kauppojen aukioloaikojen sääntely sekä alkoholin myyntiaikojen rajoitukset (45-47). Ruokatottumuksiin pyritään vaikuttamaan myös suomalaisilla ravitsemussuosituksilla, joita päivitetään kahdeksan vuoden välein (48). Asiantuntijuuden haastavassa digitalisoituvassa yhteiskunnassa on lisäksi tunnistettavissa lukuisia muita ilmiöitä, jotka muokkaavat kansalaisten mielikuvaa terveellisistä elintavoista. Mielikuvat taas potentiaalisesti vaikuttavat kotitalouksien ostoskoreihin ja sitä kautta terveyteen ja hyvinvointiin. Esimerkkejä näistä ilmiöistä ovat kampanjat kuten Tipaton tammikuu tai Lihaton lokakuu, ruokatrendit sekä kiihkeitäkin sävyjä saavuttava kansalaiskeskustelu painetussa ja sosiaalisessa mediassa. Esimerkiksi vuoden 2016 lopussa S-ryhmä alensi merkittävästi kotimaisen kurkun hinnoittelua, mikä johti kysynnän kasvuun yli tarjonnan. Kansallinen FINDIET -kyselytutkimus (49) osoitti että intensiivinen ja tunteisiin vetoava julkinen keskustelu vähähiilihydraattisesta ruokavaliosta johti voin ja tyydyttyneiden rasvojen kulutuksen vähenemisen pitkäaikaisen trendin katkeamiseen. Ostodatan avulla on mahdollista havaita kyselytutkimuksia nopeammin dynaamiset muutokset ihmisten terveyskäyttäytymisessä. Lisäksi on mahdollista selvittää keskeisimmät kansalaisten mielikuviin ja ostopäätöksiin vaikuttavat ulkoiset ohjaustekijät sekä arvioida niiden vaikutusten mittaluokkaa ja pysyvyyttä eri väestöryhmissä. Tämä voi antaa aiempaa paremmat edellytykset suunnitella terveellisempien ruokavalintojen väestöryhmäkohtaisia ohjauskeinoja

Vaikka suomalaisten terveys on kokonaisuutena viime vuosikymmeninä parantunut, on uusimman raportin mukaan tuloryhmien välinen terveyden kuilu edelleen suuri (50). Terveyden kuilu liittyy vahvasti elintapoihin kuten tupakointiin, alkoholinkäyttöön ja ruokavalioon, jotka vaihtelevat sosioekonomisen aseman mukaan (33). Ostodatan avulla on mahdollista tarkastella keskeisten kansansairauksiemme riskitekijöitä, elintapojen kasaantumista ja niiden alueellisia sekä sosioekonomisia eroja aiempaa laajemmin ja yksityiskohtaisemmin. Tutkimuksen löydöksiä voidaan käyttää eriarvoisuuden tunnistamiseen ja siihen puuttumiseen. Ostodatan yhdistäminen muihin kansallisiin väestöaineistoihin mahdollis- taa esim. sairauksien vallitsevuuden ja ilmaantuvuuden tarkastelun suhteessa elintapojen alueellisiin kasaantumisiin.

\section{KULUTTAJA-AINEISTON JA KAUPAN KANSAN- TERVEYDELLINEN ROOLI}

Kaupan roolia on perinteisesti tarkasteltu logistisesta lähtökohdasta: kauppa välittää tuotteita teollisuudelta kuluttajille. Kun otetaan huomioon pohjoismaisen päivittäistavaramarkkinan keskittyneisyys, niin kauppaketjujen tuotevalikoimaan, myymälöiden hyllykarttoihin ja tuotteiden esillepanoon liittyvien valintojen voidaan nähdä olevan merkittäviä kansanterveydellisiä päätöksiä: suomalaisten kuluttajien elintapoihin vaikutetaan näiden päätösten kautta. Tämä korostaa kaupan kansanterveydellistä valtaa ja vastuuta. Digitalisaation ja teknologian kehittymisen myötä informaatiosta tulee entistä keskeisempi liiketoiminnan osatekijä ja samalla kaupan yhteiskunnalliset vaikutusmahdollisuudet kasvavat edelleen (51). Kaupalla on tänä päivänä aiempaa paremmat edellytykset ohjata kuluttajien ostokäyttäytymistä ei vain hinnan määrittelyn vaan myös kuluttajien käyttäytymisestä ja tuotteesta jalostetun informaation avulla, mikä tarjoaa myös välineen palvella asiakasta paremmin (28). Kuluttajille jaettu informaatio voi liittyä esimerkiksi ostojen terveellisyyteen tai ympäristövaikutukseen. Tästä on jo toimivia esimerkkejä; Uudessa Seelannissa suuren kauppaketjun asiakaskohtaisia ostotietoja käytetään pohjana väestöryhmittäin kohdennetulle ravitsemusneuvonnalle (52).

Ruoka on myös merkittävä ympäristökuormituksen lähde (53). Viime vuosien tarkasteluissa ovat painottuneet etenkin ruokavalion hiilijalanjäljen sekä ruoantuotannon aiheuttaman maankäytön arvioinnit $(53,54)$. Keskeinen johtopäätös on ollut se, että etenkin naudanlihan käytön vähentäminen olisi tärkeää ruokavalion hiilijalanjäljen vähentämisessä. Ruokavalion muutokset eivät kuitenkaan ole välttämättä yksinkertaisia ja loogisia: jos lihankäytön vähentämisestä "säästyneet" kalorit korvataan runsaasti hiilinjalanjälkeä kasvattavilla vihanneksilla ja hedelmillä, voi oletettu myönteinen vaikutus hiilidioksidiemissioon olla yllättävän pieni tai jopa olematon (55). Koska ostodatasta jalostettu kotitalouskohtainen informaatio on yksityiskohtaisempaa ja henkilökohtaisempaa kuin perinteinen 
kohdistamaton valistava tieto, sillä voi olla myös vahvempi vaikuttavuus ihmisten ostokäyttäytymisen muuttamiseen.

Asiakasomistaja-aineiston hyödyntäminen tuo yrityksen aidosti mukaan yhteiskuntavastuun kantamiseen, mitä kaupparyhmät ovat viime vuosina enenevästi halunneet korostaa. LoCardtutkimus tarjoaa näyttöä yhteiskuntavastuullisen toiminnan kehittämiseksi. Yksilön omaksumien elintapojen ei voida ajatella olevan vain hänen vastuullaan. Sosioekologisen mallin (56) mukaisen makrotason on tuettava yksilön valintoja, jotta kansanterveydessä sekä eriarvoisuuden kaventamisessa voidaan saada pysyviä muutoksia aikaiseksi. Poikkitieteellinen LoCard-tutkimus hyödyntää kriittisellä otteella ajankohtaisia tiedonkeruumenetelmiä ja yhdistää terveys- ja sosiaalitieteitä ja muita tieteenaloja (sosiologia, kansanterveystiede, ravitsemustiede, alkoholitutkimus, ympäristötutkimus, biostatistiikka, terveyssosiologia, politiikantutkimus sekä palveluiden ja kaupan tutkimus). Haluamme avata vuoropuhelun, jossa päivittäistavarakaupalla yhteistyössä tutkijoiden ja muiden relevanttien yhteiskunnallisten instituutioiden kanssa on mahdollisuus toimia kansanterveyden edistäjänä, eriarvoisuuden kaventajana ja ekologisuuden korostajana. Tämä edellyttää uusia rohkeita avauksia ja yhteistyön muotoja sekä tutkijoilta että yrityksiltä ja voi parhaimmillaan johtaa merkittäviin kansanterveydellisiin ja siten myös kansantaloudellisiin hyötyihin. Yhteistyöstä kiinnostuneet tutkijat ja tutkimusryhmät voivat ottaa yhteyttä kirjoittajiin.

\section{KIITOKSET:}

Kiitämme yhteistyöstä S-ryhmää sekä ostotietonsa tutkimuskäyttöön luovuttaneita asiakasomistajia ja henkilöstöä.

\section{KIRJOITTAJIEN KONTRIBUUTIOT:}

Erkkola laati käsikirjoituksen ensimmäisen version, johon kanssakirjoittajat tuottivat tekstiä omilta osaamisalueiltaan. Erkkola, Fogelholm ja Nevalainen suunnittelivat LoCard-tutkimuksen ja yhdessä Saarijärven kanssa muodostavat tutkimuksen johtoryhmän. Nevalainen on LoCard-tutkimuksen vastaava tutkija ja teki käsikirjoituksen tilastolliset analyysit sekä kuviot. Kaikki kirjoittajat muokkasivat ja kommentoivat käsikirjoitusta ja hyväksyivät sen viimeisen version.

\section{Erkkola, M., Fogelholm, M., Saarijärvi, H., Uusitalo, L., Nevalainen, J. Customer data in public health research; case LoCard. Sosiaalilääketieteellinen aikakauslehti - Journal of Social Medicine 20 I 9: 56: 76-87.}

More attention needs to be paid to the potential of customer data for customers, research or society at large, rather than for retailer purposes alone. We introduce large and unique LoCard data, and address the potential and challenges of customer data for public health research. We contacted the holders of an S group loyalty card via email and asked for electronic informed consent to obtain purchase data for health research purposes. Data of 14595 loyalty card holders and employees consist of all food, alcohol, and tobacco purchases, spanning over a period of one year, in total > 13 million purchase events. The potential of customer data is enormous because of its size, coverage, objectivity, high resolution, and long periods of dynamic data collection, which enables timely investigations. The challenges are bias due to non-participation, product grouping, and the knowledge gap regarding what is being consumed and by whom in the household. Purchase data provide a longitudinal and less biased insight into population health behaviour and may be used as the evidence basis for interventions, policies, and health services to improve public health and reduce health inequalities. Utilizing loyalty card data for health research offers companies another way in which to fulfil their social responsibility.

Keywords: customer data, loyalty card, food purchases, public health

Saapunut $\quad 01.06 .2018$

Hyväksytty 11.10.2018 
(1) WHO. Global action plan for the prevention and control of noncommunicable diseases 20132020. WHO, Geneva, 2013. Luettu 3.5.2018. http://www.who.int/nmh/events/ncd_action_ plan/en/

(2) Schuit AJ, van Loon AJM, Tijhuis M, ym. Clustering of lifestyle risk factors in a general adult population. Prev Med 2002;35:219-224. doi: 10.1006/pmed.2002.1064

(3) Willett W. Correction for the effects of measurement error. In: Nutritional Epidemiology. Oxford University Press; 2013.

(4) Bennett DA, Landry D, Little J, ym. Systematic review of statistical approaches to quantify, or correct for, measurement error in a continuous exposure in nutritional epidemiology. BMC Med Res Methodol 2017;17:146. doi: 10.1186/s12874-017-0421-6

(5) Livingston M, Callinan S. Underreporting in alcohol surveys: whose drinking is underestimated? J Stud Alcohol Drugs 2015;76:158-164. doi: 10.15288/jsad.2015.76.158

(6) Tolonen H, Helakorpi S, Talala K, ym. 25-year trends and socio-demographic differences in response rates: Finnish adult health behaviour survey. Eur J Epidemiol 2006;21:409-415. doi: 10.1007/s10654-006-9019-8

(7) Salathé M, Bengtsson L, Bodnar TJ, ym. Digital epidemiology. PLoS Comput Biol 2012; 8:e1002616. doi: 10.1371/journal.pcbi.1002616

(8) Tuomisto JT. Massadata kansanterveyden edistämisessä. Duodecim 2012;131:2179-2187.

(9) Vayena E, Salathé M, Madoff LC, ym. Ethical challenges of big data in public health. PLoS Comput Biol 2015;11:e1003904. doi: 10.1371/journal.pcbi.1003904

(10) Tieto hyvinvoinnin ja uudistuvien palvelujen tukena - Sote-tieto hyötykäyttöön -strategia 2020. Sosiaali- ja terveysministeriön julkaisuja 2014. www.julkari.fi/handle/10024/125500.

(11) Närhinen M, Nissinen A, Puska P. Changes in supermarket sales during and after a staged health promotion campaign. Br Food J 2000;102:308-319. doi: 10.1108/00070700010327733

(12) Anderson ES, Winett RA, Wojcik JR, Winett SG, Bowden T. A computerized social cognitive intervention for nutrition behavior: direct and mediated effects on fat, fiber, fruits, and vegetables, self-efficacy, and outcome expectations among food shoppers. Ann Behav Med 2001;3:88-100. doi: 10.1207/S15324796ABM2302_3

(13) Ni Mhurchu C, Blakely T, Wall J, ym. Strategies to promote healthier food purchases: a pilot supermarket intervention study. Public Health Nutr 2007;10:608-615. doi: $10.1017 /$ S136898000735249X
(14) Haralson MK, Sargent RG, Schluchter M. The relationship between knowledge of cardiovascular dietary risk and food shopping behaviors. Am J Prev Med 1990;6:318-322. doi: 10.1016/S0749-3797(18)30976-0

(15) Närhinen M, Berg MA, Nissinen A, Puska P. Supermarket sales data: a tool for measuring regional differences in dietary habits. Public Health Nutr 1999;2:277-282. doi: 10.1017/S1368980099000373

(16) Den Hond EM, Lesaffre EE, Kesteloot HE. Regional differences in consumption of 103 fat products in Belgium: a supermarket-chain sales approach. Journal of the Am Coll Nutr 1995;14:621-627. doi: 10.1080/07315724.1995.10718551

(17) Ransley JK, Donnelly JK, Khara TN, ym. The use of supermarket till receipts to determine the fat and energy intake in a UK population. Public Health Nutr 2001;4:1279-1286. doi: 10.1079/PHN2001171

(18) Hamilton S, Mhurchu CN, Priest P. Food and nutrient availability in New Zealand: an analysis of supermarket sales data. Public Health Nutr 2007;10:1448-1455. doi: $10.1017 / S 1368980007000134$

(19) Eyles H, Jiang Y, Ni Mhurchu C. Use of household supermarket sales data to estimate nutrient intakes: a comparison with repeat 24-hour dietary recalls. J Am Diet Assoc 2010;110:106-110. doi: 10.1016/j.jada.2009.10.005

(20) Appelhans BM, French SA, Tangney CC, Powell LM, Wang Y. To what extent do food purchases reflect shoppers' diet quality and nutrient intake? Int J Behav Nutr Phys Act 2017;14:46. doi: 10.1186/s12966-017-0502-2

(21) Tin ST, Mhurchu CN, Bullen C. Supermarket sales data: feasibility and applicability in population food and nutrition monitoring. Nutr Rev 2007;65:20-30. doi: 10.1111/j.1753-4887.2007.tb00264.x

(22) Nelson M, Dyson PA, Paul AA. Family food purchases and home food consumption: comparison of nutrient contents. Br J Nutr 1985;54:373-387. doi: 10.1079/BJN19850123

(23) Becker W. Comparability of household and individual food consumption data - evidence from Sweden. Public Health Nutr 2001;4:11771182.

(24) Lund TB, Watson D, Smed S, ym. The Dietrelated GHG Index: construction and validation of a brief questionnaire-based index. Clim Change 2017;140: 503-517. doi: /10.1007/s10584-016-1869-9

(25) Yleisradio. S-ryhmä alkaa kerätä tarkempaa tietoa asiakkaista - Kuluttajaliitto tyrmistyi: "Nyt mennään pitkälle yksityiselämän asioihin" 27.7.2016. Luettu: 2.5.2018. https://yle.fi/ uutiset/3-9055737 
(26) Payne AF, Frow P. A strategic framework for customer relationship management. Journal of Marketing 2005;69:167-166. doi: 10.1509/jmkg.2005.69.4.167

(27) Jayachandran S, Sharma S, Kaufman P, Raman $\mathrm{P}$. The role of relational information processes and technology use in customer relationship management. J Mark 2005;69:177-192. doi: 10.1509/jmkg.2005.69.4.177

(28) Saarijärvi H, Karjaluoto H, Kuusela $H$. Customer relationship management: The evolving role of customer data. Market Intell Plann 2013;31:584- 600. doi: 10.1108/MIP-05-2012-0055

(29) Hansel B, Roussel R, Diguet V, Deplaude A, Chapman MJ, Bruckert E. Relationships between consumption of alcoholic beverages and healthy foods: the French supermarket cohort of 196,000 subjects. Eur J Prev Cardiol 2015;22:215-222. doi: $10.1177 / 2047487313506829$

(30) Tolonen H, Koponen P, Borodulin K, ym. Differences in participation rates between urban and rural areas are diminishing in Finland. Scand J Public Health 2018;46:755-757. doi: $10.1177 / 1403494817748737$.

(31) Koponen P, Borodulin K, Lundqvist A, Sääksjärvi K, Koskinen S (toim.). Terveys, toimintakyky ja hyvinvointi Suomessa - FinTerveys 2017-tutkimus. Terveyden ja hyvinvoinnin laitos (THL). Raportti 4/2018. Helsinki 2018.

(32) Strandhagen E, Berg C, Lissner L, ym. Selection bias in a population survey with registry linkage: potential effect on socioeconomic gradient in cardiovascular risk. Eur J Epidemiol 2010; 25:163-172.

doi: $10.1007 / \mathrm{s} 10654-010-9427-7$

(33) Laaksonen M, Silventoinen K, (toim.). Sosiaaliepidemiologia. Helsinki: Gaudeamus; 2011.

(34) PAM palvelualojen taskutilasto. Luettu 18.4.2018. https://www.pam.fi/media/1. materiaalipankki-tiedostot-nakyvat-julkisessamateriaalipankissa/tilastot-ja-tutkimukset/ palvelualojen-taskutilasto-2017.pdf

(35) Kaupan liitto. Kaupan vuosi, avainluvut 2107. Luettu 3.5.2018. http://kaupanvuosi.fi/vuosi2017lyhyesti/avainluvut/

(36) Saari J (toim.) Sosiaaliturvariippuvuus - Sosiaalipummit oleskeluyhteiskunnassa. Tampere: Tampere University Press. 2017.

(37) Statista. Statista - The portal for statistics. Luettu 15.5.2018. http://www.statista.com

(38) Nielsen. Share of consumers that have loyalty cards in selected European countries in 2016. Luettu 31.3.2018. https://www.statista.com/ statistics/792653/loyalty-card-uptake-europeancountries/

(39) Smed S, Tetens I, Bøker Lund T, ym. The consequences of unemployment on diet composition and purchase behaviour: a longitudinal study from Denmark. Public
Health Nutr 2018; 21:580-592.

doi: /10.1017/S136898001700266X

(40) Mustajoki H, Mustajoki A. A New Approach to Research Ethics: Using guided dialogue to strengthen research communities. Helsinki 2017.

(41) Shinal J. Ex-Facebook privacy manager says company cares more about data collection than protecting users. CNBC 20 Nov 2017. Luettu 15.2.2018. https://www.cnbc.com/2017/11/20/ former-facebook-privacy-manager-sandyparakilas-criticizes-zuckerberg.html

(42) Helsingin yliopiston ihmistieteiden eettisen ennakkoarvioinnin toimikunta. Tutkimuseettisten näkökulmien check list yritysyhteistyönä tehtävään ihmistieteelliseen tutkimukseen (pois lukien lääketieteellinen tutkimus). Luettu 18.4.2018. https://www. helsinki.fi/sites/default/files/atoms/files/ check_list_yritysyhteistyona_tehtavassa_ ihmistieteellisessa_tutkimuksessa_fi.pdf

(43) Euroopan parlamentin ja neuvoston asetus (EU) 2016/679. Luettu 18.4.2018. http:// eur-lex.europa.eu/legal-content/FI/TXT/ PDF/?uri=CELEX:32016R0679\&from=FI

(44) Sturm R, Patel D, Alexander E, ym. Seasonal cycles in food purchases and changes in BMI among South Africans participating in a health promotion programme. Public Health Nutr 2016;12:1-6. doi: $10.1017 / S 1368980016000902$

(45) Mytton O, Clarke D, Rayner M. Taxing unhealthy food and drinks to improve health. BMJ 2012;344:1-7. doi: 10.1136/bmj.e2931

(46) Nghiem N, Wilson N, Genc M, ym. Understanding Price Elasticities to Inform Public Health Research and Intervention Studies: Key Issues. Am J Public Health 2013;103:19541961. doi: 10.2105/AJPH.2013.301337

(47) Wagenaar AC, Salois MJ, Komro KA. Effects of beverage alcohol price and tax levels on drinking: a meta-analysis of 1003 estimates from 112 studies. Addiction 2009;104:179190. doi: 10.1111/j.1360-0443.2008.02438.x

(48) Valtion ravitsemusneuvottelukunta. Terveyttä ruoasta - suomalaiset ravitsemussuositukset 2014. Tampere: Juvenes Print; 2014.

(49) Helldán A ym. Finravinto 2012 -tutkimus. Terveyden ja hyvinvoinnin laitoksen julkaisuja. Helsinki: THL; 2013.

(50) Karvonen S, Martelin T, Kestilä L, ym. Tulotason mukaiset terveyserot ovat edelleen suuria. Tutkimuksesta tiiviisti 16/2017. Terveyden ja hyvinvoinnin laitos (THL).

(51) Saarijärvi, H, Kuusela, H, Kannan, PK, ym. Unlocking the transformative potential of customer data in retailing, The International Review of Retail, Distribution and Consumer Research 2016;26:225-241. doi: 10.1080/09593969.2015.1105846

(52) Eyles H, Rodgers A, Ni Mhurchu C. Use of electronic sales data to tailor nutrition 
education resources for an ethnically diverse population. J Hum Nutr Diet 2010; 23:38-47. doi: 10.1111/j.1365-277X.2009.01006.x

(53) van Dooren, Marinussen M, Blonk N, ym. Exploring dietary guidelines based on ecological and nutritional values: A comparison of six dietary patterns. Food Policy 2014;44:36-46. doi: 10.1016/j.foodpol.2013.11.002

(54) Bryngelsson D Wirsemius S, Hedenus F, ym. How can the EU climate targets be met? A combined analysis of technological and demand-side changes in food and agriculture. Food Policy 2016;59:152-164. doi: 10.1016/j.foodpol.2015.12.012

(55) Vieux F, Soler LG, Touazi D; ym. High nutritional quality is not associated with low greenhouse gas emissions in self-selected diets of French adults. Am J Clin Nutr 2013;97:569_ 583.

doi: 10.3945/ajen.112.035105

(56) Sallis JF, Owen N, Fisher EB. Ecological models of health behavior. Kirjassa: Glanz K, Rimer BK, Viswanath K. (toim.) Health behavior and health education: Theory, research, and practice. 4. painos. San Francisco CA: Jossey-Bass; 2008, 465-482.
Maijaliisa ERKKola

FT, ravitsemustieteen dosentti, yliopistonlehtori

Helsingin yliopisto

Elintarvike- ja ravitsemustieteiden osasto

Mikael Fogelholm

ETT, ravitsemustieteen professori

Helsingin yliopisto

Elintarvike- ja ravitsemustieteiden osasto

HANNU SAARIJÄRVI

KTT, markkinoinnin professori

Tampereen yliopisto

Johtamisen ja talouden tiedekunta

LiIsA UUSITALO

FT, tutkijatohtori

Helsingin yliopisto

Elintarvike- ja ravitsemustieteiden osasto

JAAKKO NEVALAINEN

FT, biostatistiikan professori

Tampereen yliopisto

Terveystieteiden yksikkö 